\title{
Забелов Г.В. \\ Основные требования и принципы построения бухгалтерского учета в коммерческой организации
}

Липецкий филиал Финансового Университета при Правительстве РФ

(Россия, Липецк)

doi: $10.18411 / s r-10-04-2021-108$

Научный руководитель

Шамрина И.В.

\section{Аннотация}

В данной статье рассмотрено понятие бухгалтерского учета и приведены основные требования и принципы ведения бухгалтерского учета в коммерческой организации.

Ключевые слова: бухгалтерский учет, деятельность, , коммерческая организация, основные принципы и требования.

\section{Abstract}

This article discusses the concept of accounting and provides the basic requirements and principles of accounting in a commercial organization..

Keywords: accounting, activity, commercial organization, basic principles and requirements.

В настоящее время бухгалтерский учет является одним из фундаментальных факторов, влияющих на эффективность деятельности коммерческой организации. Обязанность его проведения предусмотрена действующим законодательством. Статья 6 Закона от 06.12.2011 № 402-Ф3" О бухгалтерском учете " устанавливает, что он является обязательным для всех российских юридических лиц. Однако дело не только в требованиях закона, ведь невозможно вести бизнес, не имея информации о финансовом состоянии компании. И именно бухгалтерский учет является основным источником этой информации. Кроме того, бухгалтерская отчетность может потребоваться при получении банковских кредитов или привлечении инвестиций.

Бухгалтерский учет - это упорядоченная система сбора, регистрации и обобщения информации в денежном выражении об имуществе, обязательствах организации и их движении путем сплошного, непрерывного и документального учета всех хозяйственных операций.

Бухгалтерский учёт в соответствии с законом о бухгалтерском учёте может вестись: главным бухгалтером, принятым на предприятие по трудовому договору, генеральным директором при отсутствии бухгалтера, бухгалтером, не являющимся главным, либо сторонней организацией (бухгалтерское сопровождение).

Финансовое благополучие организации и её сотрудников напрямую связано с грамотным ведением бухгалтерского учёта, которое во многом определяется соблюдением основных требований, законодательно установленных в нашей стране (Федеральный закон от 06.12.2011 N 402-Ф3 «О бухгалтерском учете»):

1. Бухгалтерский учет имущества, обязательств и хозяйственных операций организаций ведется в валюте Российской Федерации - в рублях.

2. Имущество, являющееся собственностью организации, учитывается обособленно от имущества других юридических лиц, находящегося у данной организации.

3. Бухгалтерский учет ведется организацией непрерывно с момента ее регистрации в качестве юридического лица до реорганизации или ликвидации в порядке, установленном законодательством Российской Федерации. 
4. Организация ведет бухгалтерский учет имущества, обязательств и хозяйственных операций путем двойной записи на взаимосвязанных счетах бухгалтерского учета, включенных в рабочий план счетов бухгалтерского учета.

5. Все хозяйственные операции и результаты инвентаризации подлежат своевременной регистрации на счетах бухгалтерского учета без каких-либо пропусков или изъятий.

6. В бухгалтерском учете организаций текущие затраты на производство продукции и капитальные вложения учитываются раздельно.

Таким образом, все вышеперечисленные требования являются необходимым "фундаментом" для организации деятельности любого предприятия, без их соблюдения бухгалтерский учет становится невозможным. Но помимо основных требований, существуют и основные принципы организации бухгалтерского учета::

1. Соблюдение принятой учетной политики в течение отчетного года является обязательным для всех организаций. Как правило, эта политика предусматривает следующие требования (Приказ Минфина России от 06.10.2008 N $106 н$ (ред. От 07.02.2020) «Об утверждении положений по бухгалтерскому учету» (вместе с «Положением по бухгалтерскому учету «Учетная политика организации» (ПБУ 1/2008)): своевременность, осмотрительность (подразумевает определенную осторожность при принятии решений), приоритет содержания над формой (основанный не столько на юридической форме, сколько на экономическом содержании фактов), рациональность (рациональный учет с учетом специфики деятельности и размера организации).

2. Принцип значимости - характеризует ценность информации, означает наступление последствий в случае неправильного толкования или представления информации, тесно связан со следующим принципом.

3. Принцип полноты - в отчётности должны получить отражение все операции и результаты инвентаризации, информация должна содержать полные данные, необходимые заинтересованным лицам для последующего анализа и прогнозирования (Федеральный закон от 06.12.2011 N 402-Ф3 «О бухгалтерском учете»).

4. Принцип достоверности - информация должна содержать достоверные данные о деятельности организации, не содержать ошибок и неточностей (Федеральный закон от 06.12.2011 N 402-Ф3 «О бухгалтерском учете»).

Соблюдение перечисленных выше основных требований и принципов бухгалтерского учёта является основополагающим фактором успешного функционирования любой организации, независимо от специфики её деятельности и форм организации производства.

$$
* * *
$$

1. Бухгалтерский учет : учебное пособие [Электронный pecypc] URL: https://elar.urfu.ru/bitstream/10995/42396/1/978-5-7996-1820-9_2016.pdf

2. Бухгалтерский учет [Электронный pecypc] URL: https://www.auditit.ru/terms/accounting/bukhgalterskiy_uchet.html 